\title{
Strategi Humas Pemerintah Kota Bandung dalam Menangani Krisis Pandemi Covid-19
}

\author{
Yulia Segarwati ${ }^{1}$, Almadina Rakhmaniar ${ }^{2}$ \\ Program Studi Ilmu Komunikasi, Universitas Pasundan \\ Email: madin.archive@gmail.com
}

\begin{abstract}
Public relations has an important role in solving crisis problems. In the midst of the crisis caused by Covid-19, Public Relations of the Bandung City government needs to carry out its roles, duties and functions to carry out the strategy for handling the Covid-19 crisis. This research uses a literature study approach by collecting data or sources related to the topic raised in the research, as well as reviewing various literatures, both in the form of note and book. The data that has been obtained were analyzed using descriptive analysis method. The result shows that the Bandung City Government Public Relations crisis communication strategy in dealing with the Covid-19 pandemic crisis, in the early stages of the crisis, is to form knowledge about the COVID-19 pandemic crisis in the organization's internal environment through various communication media used by organizational members or in this case ASN and employees of the Bandung City Government. The next stage is to shape the perception of the people of Bandung City by providing message, information, and education about Covid-19, as well as socializing the policies and steps taken by the Bandung City Government in dealing with the Covid-19 pandemic crisis to the people of Bandung. Then the last strategy is to restore image and reputation through improving the quality of communication between the government and the community, as well as carrying out media relations activities to publish positive news about COVID-19 handlers in the Bandung City.
\end{abstract}

Keywords: covid-19; public relations; crisis management

\begin{abstract}
Abstrak: Humas memiliki peran penting dalam menyelesaikan masalah krisis. Di tengah krisis yang diakibatkan Covid-19 Humas pemerintah Kota Bandung perlu menjalankan peran, tugas dan fungsinya untuk menjalankan strategi penanganan krisis Covid-19. Metode penelitian ini menggunakan pendekatan studi kepustakaan dengan mengumpulkan data atau sumber yang berhubungan dengan topik yang diangkat dalam penelitian, serta melakukan penelaahan terhadap berbagai literatur, baik yang berupa catatan maupun buku. Data yang telah diperoleh dianalisis menggunakan metode analisis deskriptif. Hasil penelitian menunjukan bahwa strategi komunikasi krisis Humas Pemerintah Kota Bandung dalam menangani krisis pandemi Covid19, pada tahap awal krisis, adalah membentuk pengetahuan tentang krisis pandemi covid 19 di lingkungan internal organisasi melalui berbagai media komunikasi yang digunakan oleh anggota organisasi atau dalam hal ini ASN dan karyawan Pemerintahan Kota Bandung. Tahap selanjutnya adalah membentuk persepsi masyarakat Kota Bandung dengan memberikan pesan, informasi, dan edukasi tentang Covid-19, serta melakukan sosialisasi kebijakan dan langkah-langkah yang dilakukan Pemerintah Kota Bandung dalam menangani krisis pandemi Covid-19 kepada masyarakat Bandung. Lalu strategi yang terakhir adalah memulihkan citra dan reputasi melalui peningkatan kualitas komunikasi antara pemerintah dan masyarakat, serta menjalankan kegiatan media relations untuk mempublikasikan berita positif tentang penangan covid 19 di Kota Bandung.
\end{abstract}

Kata Kunci: covid-19; humas; manajemen krisis

\section{Pendahuluan}

Krisis adalah suatu hal yang dapat secara tiba-tiba datang tanpa disadari. Krisis berarti suatu hal yang berbahaya yang sifatnya dapat merusak dan juga berdampak buruk bagi organisasi atau lembaga. Di tengah krisis yang melanda tersebut, seorang Humas dituntut untuk 
mampu mengendalikan dampak yang dihasilkan dari krisis atau bahkan mencegah terjadinya krisis. Saat krisis terjadi, semua komponen dalam institusi atau organisasi dapat lumpuh. Itulah sebab krisis harus segera ditangani.

Salah satu cara untuk memperkecil dampak dari krisis yaitu melakukan pencegahan krisis (Pra-krisis). Humas adalah sebuah bagian dalam perusahaan atau lembaga yang dapat menjadi referensi dalam mengambil keputusan mengenai kebijakan yang akan diambil oleh suatu perusahaan, yang berarti Humas mengambil penting dalam memberikan kontribusi dalam menangani krisis (Kurniawati, 2019; Ulfa et al., 2019). Dalam hal ini Humas membuat suatu perencanaan dalam menangani suatu krisis, di mana perencanaan tersebut disebut dengan manajemen krisis. Dengan adanya manajemen krisis, Humas dapat mengatur dan mengetahui apa yang harus dilakukan ketika krisis sedang terjadi pada institusi tersebut, terlebih lagi salah satu tugas Humas adalah untuk menangani krisis (Yulianti \& Boer, 2020).

Krisis merupakan situasi yang terjadi secara tiba-tiba atau suatu keadaan yang tidak dapat dihindari oleh organisasi. Setiap organisasi atau lembaga, baik kecil maupun besar, memiliki kemungkinan untuk mengalami krisis, di mana sumbernya bisa berasal dari dalam maupun luar (Herlikano \& Lestari, 2020; Nugraha \& Choerunnisa, 2020; Maulidiyanti et al., 2018). Krisis dinilai sebagai situasi yang menyebabkan kerusakan-kerusakan fisik dan nonfisik, seperti peristiwa yang membahayakan jiwa manusia (meninggal atau luka-luka), financial cost, merusak sistem organisasi dan lingkungan secara keseluruhan, khususnya bagi korban dan kerusakan reputasi organisasi (Kriyantono, 2015). Krisis dianggap sebagai kondisi yang menakutkan sehingga banyak institusi memilih untuk menghindarinya (Jessica \& Ilfandy, 2018). Oleh sebab itu, krisis harus ditangani dengan baik. Dalam hal ini dibutuhkan manajemen krisis dan komunikasi krisis yang cepat dan tepat agar krisis tidak menyebar luas dan reputasi organisasi tetap baik di mata publik.

Pemerintah sebagai fasilitator dan regulator bagi masyarakat dalam peristiwa krisis akibat pandemi Covid-19 merupakan salah satu garda terdepan dalam bidang manajemen untuk menyelesaikan krisis. Oleh karena itu bidang kehumasan yang berperan sebagai fasilitator komunikasi mengemban tugas untuk menjalankan perannya untuk membuat dan menjalankan strategi komunikasi yang tepat untuk menangani krisis yang terjadi (Gandariani, 2019).

Komunikasi krisis memegang peranan penting dalam penanganan krisis. Komunikasi krisis bertujuan untuk menyampaikan setiap pesan agar dapat diterima dengan baik oleh pemangku kepentingan (stakeholder) dan masyarakat (Nahar, 2020). Public Relations atau Humas bertanggung jawab membantu mengatasi krisis dengan cara menjamin bahwa publik dilayani dengan baik oleh organisasi. Public Relations atau Humas menyarankan manajemen untuk menerapkan strategi komunikasi yang memungkikan organisasi beradaptasi dengan situasi di lingkungannya (Kriyantono, 2015). Dalam konteks ini Humas memiliki peran yang sangat penting untuk membuat strategi komunikasi dan diimplementasikan dengan baik agar dapat membantu manajemen krisis dan krisis dapat segera teratasi.

Humas bertugas untuk menyelesaikan masalah melalui strategi yang dimiliki oleh institusi atau lembaga dan juga menjadi fasilitator untuk menjalin hubungan baik dengan pihak eksternal dan juga internal perusahaan (Sjoraida \& Anwar, 2018). Selain itu setelah krisis terjadi seorang Humas harus mencari cara agar krisis yang serupa tidak terjadi lagi bagi institusi sehingga ketika krisis menyerang kembali institusi sudah siap untuk menanganinya sehingga krisis tersebut dapat teratasi sebelum menyerang institusi. 
Saat ini Virus Corona atau Covid-19 bukan hanya menjadi permasalahan di negara Indonesia namun tengah menjadi perhatian dunia. Kasus ini dimulai dengan pneumonia atau radang paru-parus misterius yang awalnya terjadi pada Desember 2019. Virus ini diduga berkaitan dengan pasar hewan Huanan di Wuhan yang menjual berbagai jenis binatang yang tidak lazim dikonsumsi. Kasus infeksi pneumonia misterius ini memang banyak ditemukan dipasar hewan tersebut. Virus Corona atau Covid-19 diduga dibawa kelelawar dan hewan lain yang dimakan manusia sehingga terjadi penularan.

Indonesia menjadi salah satu Negara yang terdampak wabah Covid-19. Penyebaran virus yang begitu cepat dan tingkat kematianya yang cukup tinggi, membuat pandemi Covid-19 ini menjadi krisis bagi negara Indonesia. Dampak wabah ini melanda berbagai sektor, mulai dari pemerintahan, pendidikan, ekonomi/bisnis serta kesehatan. Keresahan yang dialami masyarakat bukan hanya timbul karena penjelasan tentang virus tersebut, melainkan juga akibat dari pemberitaan yang muncul pada media massa. Sebagai media massa seharusnya dapat menjadi sarana edukasi bagi khalayak, namun yang terjadi di Indonesia adalah sebaliknya. Beberapa berita di media cenderung semakin memperkeruh keadaan. Media hanya fokus pada korban yang diduga positif terjangkit virus dibanding memberikan informasi mengenai penanggulangan atau pencegahan virus itu sendiri. Media menjadi alat propaganda yang efektif dan membentuk perilaku khalayak. Dalam keadaan darurat seperti ini kehati-hatian sangat penting agar tidak terjadi disinformasi yang dapat membuat suasana semakin tidak kondusif.

Di tengah kondisi ini, Humas pemerintahan perlu merangkul media massa agar dapat memberikan informasi yang baik, agar masyarakat tidak panik dalam menanggulangi wabah Covid-19. Humas pemerintahan harus memahami terhadap publiknya melalui perilaku komunikasi yang dilakukan oleh publik itu sendiri, memberikan informasi penting kepada publik dimana pemerintah mempunyai wewenang untuk mengendalikan masyarakat. mempersiapkan langkah awal untuk mengurangi jumlah masyarakat yang terkena virus ini, lalu tindakan seperti apa yang harus disiapkan serta dilakukan dengan tepat agar upaya pengurangan jumlah masyarakat yang terkena virus ini berjalan efektif. Dalam mempersiapkan langkah-langkah yang akan dibuat, pemerintah harus mengumpulkan beberapa data yang konkrit dari berbagai sumber sebagai media informasi untuk menyusun strategi dan memilih prosedur yang paling sesuai dalam menghadapi krisis tengah dihadapi sekarang agar memperoleh hasil atau kensekuensi yang tentunya dapat diterima, dipahami dan bisa dipatuhi oleh masyarakat.

Keberadaan atau kedudukan Humas secara lebih operasional menyatu pada fungsi dan perannya dalam suatu perusahaan ataupun organisasi. Peran Humas dalam suatu organisasi dibagi menjadi 4 kategori (Ruslan, 2014). Satu, Penasihat Ahli (Expert Preciber). Seorang praktisi Public Relations yang berpengalaman memiliki kemampuan tinggi dalam membantu mencari solusi dalam penyelesaian masalah hubungan dengan publiknya. Dalam hal ini praktisi public relations bertindak sebagai subjek dalam memecahkan dan mengatasi persoalan yang terjadi antara perusahaan dengan khalayak luas. Dua, Fasilitator Komunikasi (Communication facilitator). Praktisi Public Relations, bertindak sebagai komunikator atau mediator untuk membantu pihak manajemen dalam hal untuk mendengar apa yang diinginkan dan diharapkan oleh publiknya dari organisasi bersangkutan, sekaligus harus mampu menjelaskan kembali keinginan, harapan dan kebijakan organisasi kepada publik luas. Tiga, Fasilitator Pemecahan Masalah (Problem Solving Process Facilitator). Peran praktisi PR untuk membantu pimpinan organisasi baik sebagai penasihat hingga mengambil tindakan keputusan dalam mengatasi persoalan atau krisis yang tengah dihadapi secara rasional dan professional. Empat, Teknisi 
Komunikasi (Communication Technician). Peranan teknisi komunikasi ini menjadikan praktisi PR sebagai journalist in resident yang hanya menyediakan layanan teknis komunikasi.

Humas dalam pemerintahan berdasarkan Peraturan Menteri Negara Pendayagunaan Aparatur Negara dan Reformasi Birokrasi Republik Indonesia Nomor 29 tahun 2011 tentang Pedoman Umum Pengelolaan Komunikasi Krisis di Lingkungan Instansi Pemerintah, hubungan masyarakat pemerintah di lingkungan instansi pemerintah untuk selanjutnya disebut dengan Humas pemerintah adalah lembaga/organisasi humas dan/ atau praktisi humas pemerintah yang melakukan fungsi manajemen dalam bidang komunikasi dan informasi yang persuasif, efektif, dan efisien untuk menciptakan hubungan yang harmonis dengan publiknya melalui berbagai sarana kehumasan dalam rangka menciptakan citra positif instansi pemerintah.

Strategi komunikasi krisis merupakan bagian penting dalam manajemen krisis untuk melakukan komunikasi yang intens dengan masyarakat dan menyaring informasi-informasi yang dibutuhkan. Informasi yang kadang tidak jelas dari mana sumbernya dan kebenarannya masih dipertanyakan juga memunculkan rumor yang justru akan membingungkan masyarakat, maka dari itu peran humas harus selalu proaktif menanggapi dan dan memberikan informasi secara efektif dan efisien untuk meminimalisir informasi tersebut, karena apabila informasi tidak jelas tersebut menyebar luas maka citra organisasi pun terancam.

\section{Metode Penelitian}

Metode penelitian yang digunakan dalam penelitian ini adalah pendekatan Studi Kepustakaan (Library Research), yang bertumpu pada kajian teoritis, referensi serta literatur ilmiah lainnya yang berkaitan dengan budaya, nilai dan norma yang berkembang pada situasi sosial yang diteliti (Sugiyono, 2012). Studi Kepustakaan (Library Research) digunakan dalam mengumpulkan informasi dan data dengan bantuan berbagai macam literatur yang ada di perpustakaan seperti dokumen, buku, majalah, kisah-kisah sejarah, dan sebagainya (Arikunto \& Jabar, 2010). Sederhananya bahwa penelitian kepustakaan adalah penelitian yang memanfaatkan sumber pustaka/literatur sebagai sumber data penelitiannya, tanpa melakukan penelitian lapangan,

Sumber data dalam penelitian ini adalah buku, jurnal atau literatur-literatur lain yang sesuai dengan topik penelitian. Data-data yang dikumpulkan melalui penelaahan terhadap buku, literatur, catatan laporan atau sejenisnya untuk kemudian dianalisis menggunakan teknik analisis isi (content analysis).

\section{Hasil dan Pembahasan}

\section{Strategi Humas Pemerintah Kota Bandung dalam Menangani Krisis Pandemi Covid-19}

Humas adalah suatu rangkaian yang diorganisasikan sebagai suatu rangkaian kampanye atau program tertentu, dan semua ini berlangsung secara berkesinambungan dan teratur. Tujuan utamanya adalah menciptakan dan memelihara saling pengertian, maksudnya adalah untuk memastikan bahwa organisasi tersebut senantiasa dimengerti oleh pihak-pihak lain yang turut berkepentingan. Humas merupakan bagian dari komunikasi ini tekanannya pada komunikasi organisasi yang sasaran komunikasinya adalah untuk publik di dalam organisasi dan publik di luar organisasi, yang dimana landasan utama dari komunikasi ini adalah adanya saling pengertian diantara keseluruhan publik yang berkepentingan terhadap organisasi/perusahaan tersebut, tetapi tidak terbatas pada saling pengertian saja melainkan juga berbagai macam tujuan 
khusus lainnya seperti contoh penanggulangan masalah-masalah komunikasi yang memerlukan perubahan tertentu.

Humas mempunyai prinsip yang erat kaitannya dengan kebenaran, kejujuran, serta etika dan kepercayaan. Hal ini menegaskan bahwa pembentukan pendapat serta sikap pada setiap individu dapat terbentuk dari bagaimana sistematisnya komunikasi yang disampaikan. Dalam pelaksanaannya Humas melakukan banyak komunikasi, baik komunikasi langsung (personal contact), maupun komunikasi melalui tidak langsung atau melalui media massa agar tercipta hubungan yang baik, dari pihak internal maupun eksternal perusahaan. Humas dalam lembaga pemerintah (departemen, lembaga nondepartemen, Badan Usaha Milik Negara/BUMN) merupakan suatu keharusan fungsional dalam rangka tugas penyebaran informasi tentang kebijakan, program dan kegiatan-kegiatan lembaga pemerintahan kepada masyarakat. Humas pemerintah bertugas memberikan informasi dan penjelasan kepada khalayak/publik mengenai kebijakan dan langkah-langkah/ tindakan yang di ambil oleh pemerintahan serta mengusahakan tumbuhnya hubungan yang harmonis antara lembaga/instansi dengan publiknya dan memberikan pengertian kepada publik (masyarakat) tentang apa yang dikerjakan oleh instansi pemerintahan di mana Humas itu berada dan berfungsi (Rachmadi F, 1994:78).

Ada beberapa tugas pokok Humas pada lembaga pemerintahan. Satu, memberikan penerangan dan pendidikan kepada masyarakat tentang kebijakan, langkah-langkah dan tindakan-tindakan pemerintah, serta memberikan pelayanan terbuka, jujur, dan objektif. Dua, memberikan bantuan kepada media massa (mass media) berupa bahan-bahan informasi mengenai kebijakan, langkah, dan tindakan pemerintah, termasuk fasilitas peliputan kepada media berita untuk acara resmi. Tiga, mempromosikan kemajuan pembangunan ekonomi dan kebudayaan yang telah dicapai kepada khalayak. Empat, memonitor pendapat umum tentang kebijakan pemerintah, serta menyampaikan tanggapan masyarakat dalam bentuk feed back kepada pimpinan instansi pemerintah (Rachmadi, 1994). Sementara itu, dalam literatur yang lain, tugas humas pada Departemen Pemerintahan adalah (1) menyebarkan informasi secara teratur mengenai kebijaksanaan, perencanaan, dan hasil yang telah dicapai, (2) menerangkan dan mendidik public mengenai perundang-undangan, peraturan- peraturan dan hal-hal yang bersangkutan dengan kehidupan sehari-hari, (3) menasehati pemimpin departemen dalam hubungannya dengan reaksi atau tanggapan balik publik terhadap kebijaksanaan yang telah dijalankan (Effendy, 1992).

Krisis dianggap membawa perubahan negatif dalam urusan keamanan, ekonomi, politik, sosial, atau lingkungan, terutama ketika krisis terjadi tiba-tiba, dengan sedikit atau tanpa peringatan. Lebih jauh, krisis adalah istilah yang berarti "waktu pengujian" atau "peristiwa darurat". Krisis merupakan suatu turning point for better or worse titik balik untuk makin baik atau makin buruk. Dapat dikatakan juga bahwa krisis adalah suatu waktu yang krusial atau momen yang menentukan decisive moment (Kasali, 2003). Dapat disimpulkan bahwa krisis merupakan suatu peristiwa yang sedang terjadi atau diperkirakan yang mengarah pada situasi tidak stabil dan berbahaya jika tidak diatasi dengan baik, situasi yang berbahaya tersebut apabila diatasi dengan baik maka dapat dijadikan sebagai turning point untuk membuat organisasi atau perusahaan menjadi lebih baik. Oleh karena itu, dibutuhkan keahlian seorang Humas untuk memiliki kemampuan manajemen krisis yang baik.

Sebelum terjadi krisis dan berupaya dalam menangani krisis seorang praktisi Humas harus mengetahui terlebih dahulu tipe atau jenis-jenis krisis yang mungkin muncul. Ini diperlukan karena respons atas krisis sedikit banyak akan bergantung pada tipe krisis yang 
bersangkutan. Seorang praktisi Humas perlu mengenali tipe-tipe krisis sebagaimana yang dikemukakan Reinhardt-dikutip Cutip \& Center-bahwa krisis bisa saja bersifat segera (immediate crises). Ini tipe krisis yang paling ditakuti karena terjadi tiba-tiba, tidak terduga dan tidak diharapkan. Tidak ada waktu untuk melakukan riset dan perencanaan. Krisis ini membutuhkan konsensus terlebih dahulu pada level manajemen puncak untuk mempersiapkan rencana umum (general plan) mengenai bagaimana reaksi jika terjadi krisis yang bersifat segera agar tidak menimbulkan kebingungan, konflik dan penundaan dalam menangani krisis yang muncul. Tipe krisis selanjutnya krisis yang baru muncul (emerging crises). Tipe krisis ini masih memungkinkan praktisi Humas untuk melakukan penelitian dan perencanaan terlebih dahulu, namun krisis dapat meledak jika tidak ditangani. Tantangan Humas jika terjadi krisis jenis ini adalah meyakinkan manajemen puncak untuk mengambil tindakan perbaikan sebelum krisis mencapai tahapan krisis. Yang terakhir adalah tipe krisis bertahan (sustained crises). Tipe krisis ini adalah krisis yang tetap muncul selama berbulan-bulan bahkan bertahun-tahun walaupun telah dilakukan upaya terbaik oleh pihak manejemen perusahaan atau organisasi untuk mengatasinya (Morissan, 2008).

Secara konseptual, anatomi krisis dibedakan ke dalam empat tahap. Pertama, tahap prodromal, di mana krisis baru muncul dan belum mempunyai dampak yang luas terhadap citra korporasi/institusi. Tahap ini sering disebut dengan warning stage karena pada tahap ini peringatan terhadap datangnya krisis bagi sebuah perusahaan atau institusi. Pada tahap prodromal muncul dalam 3 bentuk, yaitu (a) jelas sekali, di mana krisis muncul dengan jelas, (b) Samar-samar. Krisis susah diduga luasnya sebuah kejadian dalam bentuk ini. Permasalahan tidak terlihat jelas atau samar-samar, (c) Sama sekali tidak terlihat. Biasanya perusahaan atau institusi tidak menyadari datangnya krisis ini karena semua terlihat baik baik saja (gejala tidak terlihat). Kedua, tahap akut, merupakan pola krisis dimana persoalan muncul ke permukaan. Krisis pada tahap akut juga sering disebut the point of no return yang artinya sesekali sinyal-sinyal yang muncul pada tahap peringatan (prodromal stage) tidak digubris, ia akan masuk ke tahap akut dan tidak dapat kembali lagi. Ketiga, tahap kronik, di mana krisis telah berlalu dan yang tersisa hanyalah puing-puing masalah akibat krisis. Sering juga disebut dengan the postmortem atau the clean up phase. Keempat, tahap resolusi, yaitu tahap di mana manajemen harus memulihkan kekuatan agar kembali seperti semula dan dapat melanjutkan aktivitas dengan normal dan lancar. Ini merupakan tahap penyembuhan. Namun harus tetap waspada karena biasanya siklus pembentukan krisis sedang membentuk kembali (Kasali, 2003).

Humas Pemerintah Kota Bandung sebagai salah satu kota yang terdampak dari Covid-19 dapat dikatakan sedang mengalami krisis. Krisis merupakan suatu ancaman bagi organsisasi atau krisis menciptakan organisasi dalam posisi menjadi perhatian masyarakat sehingga mempertanyakan kompetensi manajemen organisasi. Oleh sebab itu organisasi / lembaga dalam hal ini pemerintahan harus berkomunikasi dengan cepat dan terampil dengan berbagai kelompok penting seperti stakeholder dan pihak penting lainnya terkait dengan keberhasilan jalannya perusahaan atau organisasi.

Peran manajemen krisis yang baik adalah menjadikan Humas Pemerintah kompeten dalam menjalankan tugas sehingga dapat menyelesaikan krisis tersebut. Seperti yang dikemukakan Kasali (2003), krisis merupakan suatu turning point for better or worse, titik balik untuk semakin baik atau semakin buruk. Dapat dikatakan juga bahwa krisis adalah kondisi yang krusial atau momen yang menentukan (decisive moment). Oleh karena itu Humas Pemerintah 
Kota Bandung melakukan peran dan manajemen krisis yang baik karena pada dasarnya jika krisis ditangani dengan baik maka akan melahirkah "pahlawan" bagi publiknya.

Ruslan (2014) menjelaskan bahwa dalam menjalankan kegiatannya Humas memiliki beberapa peran. Pertama, Humas bisa berperan sebagai Penasihat Ahli. Seorang praktisi pakar Humas yang berpengalaman dan memiliki kemampuan tinggi dapat membantu mencarikan solusi dalam penyelesaian masalah hubungan dengan publiknya (Public Relationship). Humas pada praktiknya dapat membantu menjadi penasehat ahli dalam masalah yang dihadapi oleh instansi atau organisasi. Kedua, berperan sebagai Fasilitator Komunikasi. Praktisi Humas bertindak sebagai komunikator atau mediator untuk membantu pihak manajemen untuk mendengar apa yang diinginkan dan diharapkan publik. Di sisi lain Humas harus mampu membangun hubungan baik dengan publik serta menjelaskan kembali harapan, keinginan dan kebijakan organisasi atau instansi agar terjadi komunikasi timbal balik yang saling mendukung, terciptanya pengertian dan menghargai antara kedua belah pihak. Ketiga, sebagai Fasilitator Pemecahan Masalah. Peranan praktisi Humas dalam proses pemecahan persoalan Humas ini merupakan bagian dari tim manajemen. Hal ini dimaksudkan untuk membantu pemimpin organisasi baik sebagai penasihat (adviser) hingga mengambil tindakan eksekusi (keputusan) dalam mengatasi persoalan atau krisis yang tengah dihadapi secara rasional dan profesional. Keempat, berperan sebagai Teknik Komunikasi. Berbeda dengan tiga peranan praktisi Humas profesional sebelumnya yang terkait erat dengan fungsi dan peranan manajemen organisasi, peranan communication technician ini menjadikan praktisi Humas sebagai journalist in resident yang hanya menyediakan layanan teknis komunikasi atau dikenal dengan method of communication.

Dapat dikatakan, ada banyak langkah yang perlu dilakukan Humas Pemerintah dalam menangani masalah krisis. Hal ini secara gamblang dapat dijelaskan bahwa dalam menangani krisis Humas Pemerintah Kota Bandung dalam menangani krisis Covid-19 harus melakukan langkah-langkah manajemen krisis terntentu. Langkah-langkah tersebut adalah (1) Mempersiapkan contingency plan (anggota tim krisis manajemen dapat dibentuk dalam waktu singkat, selalu diadakan pelatihan untuk menghadapi berbagai macam krisis), (2) Segera mengumumkan official spokesperson (anggota tim krisis) yang berhak bicara dan memberikan keterangan mengenai krisis ke publik dan media, (3) Bergerak cepat (jam pertama ketika krisis terjadi sangat crusial, karena media sering memberikan informasi berdasarkan kejadian awal krisis), (4) Menggunakan konsultan manajemen krisis (saran dari konsultan Humas sangat penting), (5) Memberikan informasi yang akurat dan benar (perlu diingat ketika mencoba untuk memanipulasi informasi akan berbalik menjadi bahaya jika kebenaran ditemukan), dan (6) Ketika memutuskan bertindak, jangan hanya mempertimbangkan kerugian jangka pendek, tetapi pikirkan juga efek jangka panjang (Nova, 2011).

Langkah-langkah tersebut relevan dengan kemampuan manajemen krisis yang harus dimiliki oleh praktisi Humas Pemerintah Kota Bandung yang kini tengah mengalami krisis akibat pandemi Covid-19. Tingkat penularan Covid-19 semakin tinggi setiap harinya. Virus ini seolah tidak dapat dikendalikan hingga menyebar ke suluruh penjuru Nusantara. Demkikian juga yang terjadi di Kota Bandung. Pandemi covid 19 merupakan fenomena yang sangat kompleks, hingga menimbulkan krisis di berbagai aspek. Oleh sebab itu, komunikasi memiliki peranan yang sangat penting dalam penanganan krisis akibat Covid-19. Langkah awal dalam melakukan penanganan krisis yaitu membentuk pengetahuan tentang pandemi covid 19 di lingkungan 
organisasi untuk menyamakan persepsi di antara seluruh internal organisasi sehingga koordinasi dan penanganan krisis dapat berjalan dengan baik.

Humas Pemerintah Kota Bandung memanfaatkan perkembangan teknologi komunikasi dalam melakukan strategi penanganan krisis. Sebagai contoh, pemerintah menyampaikan sosialisasi dan melakukan upaya penangan krisis melalui aplikasi komunikasi daring seperti WhatsApp group, zoom meeting, dan lain sebagainya. Pengetahuan krisis Covid-19 di internal organisasi Pemerintah Kota Bandung terbentuk dari berita tentang Covid-19 diperoleh dari tim Gugus Tugas penanganan Covid-19 yang merupakan tim krisis untuk penyelesaian pandemi Covid-19 sendiri dan instruksi dari Wali Kota dan Wakil Wali Kota sebagai pemimpin Pemerintahan Kota Bandung. Berita, informasi, instruksi dan kebijakan tersebut dibagikan melalui aplikasi percakapan media sosial internal Pemerintah Kota Bandung sehingga memungkinkan terbentuknya pengetahuan tentang krisis di internal Pemerintah Kota Bandung.

Pemanfaatan media komunikasi online untuk membentuk pengetahuan tentang krisis pandemi covid 19 ini bukan menjadi yang utama. Humas Pemerintah Kota Bandung dan Diskominfo Kota Bandung juga memanfaatkan media lain, salah satunya adalah majalah Kota Bandung yang terbit satu bulan sekali dan tersebar di seluruh wilayah kantor Pemerintahan Kota Bandung. Selama pandemi Covid-19, majalah ini berisi informasi tentang edukasi Covid-19, mulai dari data, edukasi protokol kesehatan dan kebijakan terbaru tentang Covid-19 Kota Bandung. Majalah ini menjadi salah satu media offline yang menyebarkan informasi lengkap untuk menambah pengetahuan tentang pandemi Covid-19 khususnya bagi internal pemerintah Kota Bandung.

Baliho dan spanduk juga dimanfaatkan humas Pemerintah kota Bandung sebagai media komunikasi untuk membentuk pengetahuan tentang krisis pandemi Covid-19. Media-media tersebut tersebar di setiap sudut wilayah perkantoran pemerintahan Kota Bandung. Pesan yang ditujukan pun sama, yaitu edukasi dan informasi tentang pandemi Covid-19 yang dikhususkan bagi internal organisasi, tamu dan masyarakat yang berada di lingkungan Pemerintahan Kota Bandung. Hal ini menunjukan keseriusan Humas Pemerintah Kota Bandung dalam membentuk pengetahuan tentang pandemi Covid-19 baik bagi internal Pemerintahan Kota Bandung maupun masyarakat luas. Pembentukan pengetahuan tentang krisis pandemi Covid-19 di internal organisasi Pemerintah Kota Bandung begitu intensif dilakukan dengan memanfaatkan berbagai media komunikasi. Hal tersebut dilakukan sebagai upaya Humas Pemerintah Kota Bandung untuk menyamakan persepsi seluruh ASN tentang krisis yang terjadi.

\section{Kesimpulan}

Humas Pemerintah Kota Bandung menjadi salah satu elemen yang bertanggung jawab dalam menangani krisis akibat Covid-19. Humas Pemerintah Kota Bandung merencanakan dan menerapkan beberapa strategi komunikasi krisis menangani krisis pandemi Covid-19. Dalam hal ini, Humas Pemerintah Kota Bandung membentuk pengetahuan tentang krisis pandemi covid 19 dilingkungan internal organisasi, untuk menyamakan persepsi anggota organisasi terhadap krisis yang terjadi humas pemerintah Kota Bandung menggunakan berbagai macam media komunikasi untuk memberikan informasi tentang covid 19 baik berupa kebijakan, aturan ataupun himbauan, dengan adanya persamaan persespsi terhadap krisis maka mempermudah komunikasi dan koordinasi untuk menjalankan strategi komunikasi selanjutnya. Hal tersebut merupakan strategi awal yang dilakukan oleh humas Pemerintah Kota Bandung dalam menjalankan strategi komunikasi krisisnya. 
Humas Pemerintah Kota Bandung juga membentuk persepsi masyarakat tentang krisis pandemi covid 19 dengan membuat pesan dan informasi tentang krisis yang disebarkan melalui berbagai media komunikasi yang digunakan oleh publik. Membagikan berita atau informasi tentang upaya yang dilakukan oleh Pemerintah Kota Bandung kepada masyarakat. Hal tersebut bertujuan untuk memperoleh persepsi yang baik dari masyarakat terhadap Pemerintah Kota Bandung. Selain itu, juga dilakukan jalinan hubungan yang baik dan konstruktif antara pihak pemerintah dengan media massa, seperti penerbitan siaran pers dan pelaksanaan konferensi pers mengenai informasi positif Pemerintah Kota Bandung. Komunikasi dengan masyarakat juga terus dimaksimalkan melalui forum komunikasi dua arah yang dilakukan secara virtual. Humas Pemerintah Kota Bandung juga membuat website terpusat untuk memperbaharui informasi seputar Covid-19. Penerapan strategi-strategi ini menggambarkan keseriusan Humas pemerintah Kota Bandung dalam menangani krisis pandemi Covid-19.

\section{Daftar Pustaka}

Arikunto, S., \& Jabar, A. S. C. (2010). Evaluasi Program Pendidikan. Bumi Aksara.

Effendy, O. U. (1992). Hubungan Mayarakat Suatu Komunikologis. PT. Remaja Rosdakarya.

Gandariani, T. (2019). Perencanaan Krisis PR: Sebuah Upaya Strategi Komunikasi Mengatasi Krisis. Jurnal Lentera Komunikasi (Vol. 3, Issue 1).

Herlikano, R. O. S., \& Lestari, M. T. (2020). Strategi Komunikasi Krisis Hubungan Masyarakat PT Angkasa Pura I (Persero) Yogyakarta dalam Mengatasi Krisis Pemberitaan pada Media Selama Proses Pembangunan Bandara Internasional di Kulon Progo. E-Proceeding of Management, 7694-7702.

Jessica, S., \& Ilfandy, A. (2018). Aktivitas Public Relations Angkasa Pura II Dalam Menangani Pemberitaan Negatif Terminal 3 Bandara Soekarno-Hatta. Jurnal Ilmiah Ilmu Hubungan Masyarakat (Profesi Humas), 2(2), 119- 135.

Kasali, R. (2003). Manajemen Public Relations: Konsep dan Aplikasinya di Indonesia. PT. Pusaka Utama Grafiti.

Kriyantono, R. (2015). Public Relations \& Crisis Management (Pendekatan Critical Public Relations Etnografi Kritis \& Kualitatif). Kencana.

Kurniawati, J. (2019). Komunikasi Krisis di Era Digital. INTELEKTIVA: Jurnal Ekonomi, Sosial \& Humaniora KOMUNIKASI, 1(2), 50-61.

Maulidiyanti, M., Suciati, P., Sinawang, L. P., \& Lusia, A. (2018). Opini Mahasiswa Atas Strategi Humas dalam Menangani Isu dan Krisis. Prosiding Seminar Nasional Jambore Nasional Komunikasi II - 2018.

Morissan. (2008). Manajemen Media Penyiaran: Strategi mengelola Radio dan Televisi. Kencana Prenada Media Group.

Nahar, L. (2020). Komunikasi Krisis Pemerintah Indonesia Menghadapi Pandemi Covid-19. Jurnal Syntax Admiration, 5(1), 553-566.

Nova, F. (2011). Crisis Public Relations Bagaimana PR menangani krisis Perusahaan. Raja Grafindo Persada.

Nugraha, A. R., \& Choerunnisa, S. (2020). Strategi Manajemen Krisis Humas PLN UID Jabar dalam Menangani Blackout Jaringan Jawa Bagian Tengah. Communiverse: Jurnal Ilmu Komunikasi, 5(2), 137-150. https://doi.org/10.36341/cmv.v5i2.1136

Rachmadi, F. (1994). Public Relations dalam Teori dan Praktek. Gramedia Pustaka Utama.

Ruslan, R. (2014). Manajemen Public Relations \& Media Komunikasi. Raja Grafindo Persada.

Sjoraida, D. F., \& Anwar, R. K. (2018). Pola Komunikasi Humas Rumah Sakit di Era Digital. Socio-Politica, 8, 148-162.

Sugiyono. (2012). Metode Penelitian Kuantitatif Kualitatif dan R\&D. Alfabeta. 
Ulfa, N., Suadnya, W., \& Khusnia, H. N. (2019). Manajemen Krisis Humas Pemerintah Daerah Kabupaten Lombok Utara Pada Saat Gempa Bumi Lombok 2018. JCommSci-Journal Of Media and Communication Science, 2(2), 97-115.

Yulianti, W., \& Boer, R. F. (2020). Manajemen krisis public relations dalam menangani penolakan imunisasi measles rubella. PRofesi Humas Jurnal Ilmiah Ilmu Hubungan Masyarakat, 4(2), 290-311. https://doi.org/10.24198/prh.v4i2.23700 